\title{
Business Combinations under Common Control: The Gain/loss Group Perspective. What the IASB Project Leaves Unaddressed
}

\author{
Francesco Bellandi ${ }^{1}$ \\ ${ }^{1}$ Head of Technical Accounting, Multinational, London, UK \\ Correspondence: Francesco Bellandi, Head of Technical Accounting, Multinational, London, UK. E-mail: \\ Francesco_bellandi@yahoo.com
}

Received: August 16, 2021

Accepted: September 20, 2021 Online Published: October 6, 2021

doi:10.5539/ijbm.v16n11p59

URL: https://doi.org/10.5539/ijbm.v16n11p59

\begin{abstract}
Although BCUCCs are widespread, a clear treatment is missing under IFRS. Most contributions have taken partial views. This article innovatively provides a systematic theoretical apparatus of the role accounting plays for all the affected members of a group, with a focus on gain or loss opportunities below the consolidated statements. The method used is international technical accounting analysis under IFRS and U.S. GAAP. It shows how a BCUCC may be driven to achieve gain/loss in separate financial statements and how cross-company consistency in policies and substance may reveal gain/loss arbitrage; the interaction of principles for disposals, demergers, and business combinations; and the position of sub-holdings, which in real practice is more relevant than the ultimate parent company. This paper is timely, as the IASB has recently published a Discussion Paper. The IASB project fails to give answers to these points as it only looks at the receiving entity and consolidated statements.
\end{abstract}

Keywords: Business combination, common control, IFRS 3, Topic 805

\section{Introduction}

Notwithstanding the frequency and significance of business combinations under common control (i.e., between members of the same group, hereafter BCUCCs), a clear set of accounting principles is missing under IFRS. Therefore, company practice is diverse, and entities need to develop their own accounting policies, often by looking at U.S. GAAP and national GAAPs. IASB (2020), IFRS 3, para. B1 defines a business combination under common control as where all the combining entities or businesses are ultimately controlled by the same party or parties both before and after the business combination, and control is not transitory. Common control also exists when there is a contractual arrangement that gives a group of individuals with non-transitory ultimate power to govern the financial and operating policies to obtain benefits from its activities (IASB 2020, IFRS 3, para. B2). Under U.S. GAAP, Financial Accounting Standards Board (FASB 2020), FASB ASC 805-50-15-6 does not define common control but illustrates it by means of examples. FASB (2005), EITF 02-5, superseded, suggested that common control of separate entities exists when there is more than $50 \%$ voting ownership interest by the same enterprise or individual or their immediate family members (including married couple and their children) with no evidence of voting other than in concert, or by a group of shareholders with contemporaneous written evidence of an agreement to vote a majority of shares in concert.

In 2007 the International Accounting Standards Board (IASB) started a project on this subject, and in 2020 it published a Discussion Paper, a fact that makes this article timely. The IASB project addresses BCUCCs from the perspective of the consolidated financial statements of the receiving entity, with a particular focus on the presence of noncontrolling interests. Conversely, multinational groups often look at BCUCCs to achieve gain opportunities below the consolidated statements of a wholly consolidated group (this article explicitly focuses only on BCUCC where there is no presence of non-controlling interests). Of course, the impact of this perspective in the BCUCC project is relevant in countries where separate accounts are also allowed to, or must comply with, IFRS. European Financial Reporting Advisory Group (EFRAG 2011) has been an important contributor to the IASB Project. It also focuses on the consolidated financial statements of the receiving entity.

Consequently, the research question of this article is: what accounting methods could conceptually justify the recognition of gains or losses in a BCUCC, and what critical aspects and grey areas does this raise, and does the IASB Project address these aspects? The article shows how gain/loss opportunities are often exploited by 
leveraging current grey areas for which IFRS guidance is missing, even after the IASB Project.

Literature is fragmented and partial and has largely focused on the consolidated receiving entity. This article constructs a theoretical and systematic apparatus about the group dynamics of gain and loss opportunities resulting from the interaction of the financial statements of all the members affected, including intermediate parents, an aspect which is completely ignored by the IASB project, taking for granted that it is already treated by accounting standards, while this is not fully the case in the context of transactions under common control.

After literature review, research questions and method followed, the technical analysis is divided in six sections from the perspectives of 1) the consolidated financial statements of the receiving entity; 2) the individual financial statements of the receiving entity; 3) the separate financial statements of the receiving entity and higher-level parent; 4) the transferor; 5) interactions with demergers or spin-offs for the transferor; and 6) the individual financial statements of the transferred entity. Finally, the conclusions summarise the key interactions and critical aspects to look at to plan for a BCUCC under conditions of not gain or loss indifference. Note: accounting pronouncements date is reported as the latest date in which they have been amended.

\section{Literature Review}

Before moving to BCUCCs, it is legitimate to see whether profit or loss effects have been identified as key factors in business combinations in general. Elnahass et al. (2019) find that while bargain purchase gains in business combinations are not generally a strong factor in valuations, they have been positively valued by the market after the revision of IFRS 3 when properly disclosed. Hamberg et al. (2011) report positive stock market reactions in Sweden due to IFRS 3 goodwill impairment loss lower than prior GAAP amortisation. Cavero Rubio et al. (2020) also investigate the incentives given by goodwill and restricted impairment testing.

Moving to BCUCCs, academic literature is scarce and has not generally studied the gain or loss dimension in that context. Onesti et al. (2015) provide a comprehensive comparison of different approaches. Fiume et al. (2015) have compared different methods of accounting for BCUCC. Janowicz (2017) claims that authoritative guidance is necessary for BCUCC as the analogy to national GAAPs would not lead to a fully compliance development of an accounting policy under IASB (2018), IAS 8. Biancone (2013) analyses pooling versus the purchase method on BCUCC for companies listed on Italian stock exchange and on FTSE MIB. Bonacchi et al. (2015) highlight the connection between the issuance of public debt and previous BCUCC accounted for at acquisition method to conclude that the use of fair value method is induced by the reduction of accounting leverage. Baker et al. (2009) challenge the elimination of the pooling method by studying the Chinese accounting principles.

In the absence of additional literature on BCUCC, the next level of review may be on accounting methods that might be employed in a BCUCC even if not studied in that context. Aboody et al. (2000) have investigated purchase vs. pooling methods of accounting and found a positive association between CEO earnings-based compensation and pooling and between the purchase method and firm's debt-to-equity ratio. Baker et al. (2010) focus on comparative financial analysis of the impact of the pooling method versus the purchase method in Chinese accounting for BCUCC. Asís Martínez-Jerez (2008) investigates the effect on stock price of purchase versus pooling-of-interest accounting. Rayburn et al. (1991) illustrate a thorough history of the pooling method. To explain, the term 'book value' accounting may comprise different methods. Under IASC (1999), IAS 22, superseded, paras. 78-84, $\mathrm{BC} 29-\mathrm{BC} 30, \mathrm{BC} 35$, the pooling of interests methods was used to account for unitings of interests, which applied to a continuation of the mutual sharing of risks and benefits for so-called true mergers or mergers of equals, i.e., combinations of entities of approximately equal size or where it was difficult to identify an acquirer, with stock exchange as predominant form of consideration, no new capital invested and no assets distributed, and post-combination ownership interests proportional to those before the combination. The resulting single combined entity recognised the carrying amounts of the combining enterprises, after eliminating any intercompany transactions and conforming for uniform accounting policies. U.S. GAAP also used the pooling of interests method. However, while IASC (1999), IAS 22 did not mention this method in relation to BCUCCs, although in practice its applicability was extended to them, U.S. GAAP then superseded it except for transactions between entities under common control (FASB 2020, FASB ASC 805-50-05-5) under the name of predecessor's carryover basis. The entity that receives the assets and liabilities initially recognises them at their carrying amount in the books of the transferring entity at the date of transfer, or at the historical cost of the parent of the entities under common control if different. Adjustments are made to uniform accounting policies, normally to those of the receiving entity if this is preferable (FASB 2020, FASB ASC 805-50-30-5 to 6). Unlike IASC (1999), IAS 22, the assets and liabilities, net income and retained earnings are included at controlling interest's share. 
This paper moves from the observation that BCUCCs exist in company practice beyond the need for a group reorganisation. The hypothesis is that current latitude in accounting standards permits a degree of freedom to manage earnings within a group even in transactions with no minority interests. If this hypothesis is proved, the field would be subject to further research.

\section{Method}

As the literature review has shown, most contributions have addressed the lack of a specific standard, the impact on the financials of different accounting methods, and surveys of companies' practice from the perspective of the receiving entity. The perspective adopted by the IASB project, as well as by EFRAG (2011), is that of the receiving entity. In contrast to the fragmented and partial approach of most existing papers, this article shows the role of gain opportunities in accounting for BCUCCs by a systematic apparatus of current guidance and a critical review of the different perspectives of the members of the group.

The research question is: what accounting methods could conceptually justify the recognition of gains or losses in a BCUCC, and what critical aspects and grey areas does this raise, and does the IASB Project address these aspects? The clearly stated scope of this article is to address this research hypothesis from a purely theoretical basis (i.e., from a technical accounting analysis), not from empirical evidence from collecting data. The paper is about detailing the flexibility of the mechanics of the transaction to show how the current flexibility and grey areas in accounting standards do in practice open arbitrage opportunities.

The material used by this article to contribute to fill the gap in literature includes a deep review of IFRS and U.S. GAAP. The article also looks at U.S. GAAP because of the IASB (2018), IAS 8, para. 12 guidance for developing and applying an accounting policy, which also comprises consideration of other GAAPs that use a similar conceptual framework (IFRS and U.S. GAAP now have a Common Conceptual Framework).

The method used is international technical accounting analysis, to address the practical question of how to account for an inter-company transfer of a 'target', which currently reports to an intermediate parent company, to another intermediate parent company (Figure 1). This transaction is apparently simple, explicitly excluding more complex situations with the presence of non-controlling interests, but this is enough to illustrate several complex issues. The analysis is from the perspective of the transferor, the acquirer, the transferred company, the two intermediate parents and the ultimate parents, and for all of them in both their consolidated and separated financial statements. 'Target' here may be a company, a business within that company, or a group of assets and liabilities that is not a business. The transaction may be for a consideration or without consideration. This analysis is developed under IFRS and U.S. GAAP, and finally compared with the tentative decisions of the IASB project.

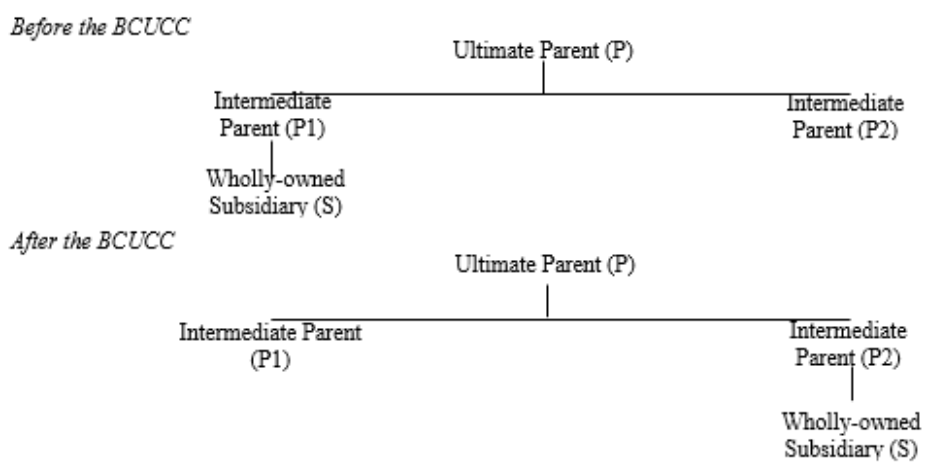

Figure 1. Inter-company transfer used for analysis

\section{Analysis and Results}

\subsection{Perspective of the Consolidated Financial Statements of the Receiving Entity}

4.1.1 Accounting Options in Consolidated Financial Statements

IASB (2020), IFRS 3, para. 2 scopes out a business combination under common control. Its silence has sometimes been interpreted as an accounting policy choice between IASB (2020), IFRS 3 or book value (for 
example, EY 2020, para. 10.3.1, KPMG 5.13.40.10, Price Water house Coopers (PWC 2020), para. A1.14). This has often been justified based on IASB (2018), IAS 8 paras. 10-11 principles for developing an accounting policy in the absence of a specifically applicable IFRS, by first looking at IFRSs dealing with similar issues (IASB 2020, IFRS 3 in this case), or other GAAPs, such as U.S. GAAP. This choice must be justified, and this poses questions on the consistency of accounting policies that are applicable to more than one BCUCC. In fact, under IASB (2018), IAS 8 para.14, an entity can voluntarily change an accounting policy that is allowed by IFRS only if it results in the financial statements providing reliable and more relevant information about the effects of transactions, other events and conditions on the entity's financial position, financial performance, and cash flows. It may be argued that if a key rationale for the IASB (2020), IFRS 3 scope exclusion is that there is no acquisition of control, it may be difficult to see how an IASB (2018), IAS 8 development of accounting policy could result in applying IASB (2020), IFRS 3 by analogy, when IASB (2020), IFRS 3, para. A defines a business combination as a transaction or other event in which the acquirer obtains control of one or more businesses. In addition, some have maintained that even if a company uses book value in this context, the process in IASB (2020), IFRS 3 should be applied in its entirety by analogy because the transaction remains a business combination (KPMG 2020, para. 5.13.70.10). The Committee of European Securities Regulators (CESR 2008), 08-283, Decision ref EECS/0508-04 ruled that the application of pooling of interests under U.S. GAAP to a BCUCC was acceptable for an IFRS issuer. In another ruling, CESR (2008), 08-966, Decision ref EECS/1208-01 enforced the use of book value in a reverse business combination under common control. Finally, while IASB (2020), IFRS 3 scopes out BCUCCs, IASB (2018), IFRS 5 is silent on this and does not have any formal exclusions. Based on the Efrag Paper, IASB (2020), IFRS 3 may be appropriate if the ultimate parent entity is seen as not a primary user of, as it need not rely on, the consolidated financial statements of the receiving entity, while it may not be such in the opposite situation, as well as when lenders look at the separate/individual financial statements of the combining entities. Like IASB (2020), IFRS 3, FASB (2020), FASB ASC 805-10-15-4 scopes out business combinations under common control. However, unlike IASB (2020), IFRS 3, it does have guidance by grandfathering the previous treatment of the so-called 'predecessor's carryover basis' (see below).

\subsubsection{The Debate on the Concept of Substance}

The purpose of this paragraph is to show the judgmental nature of determining the reason for a transaction involving a group and whether that is a real business combination, a BCUCC, or a reorganisation, heading for different accounting methods and profit or loss implications. In its latest tentative decisions, the IASB Project simply bypasses this topic by a rules-based approach.

There is no specific requirement in IFRS about substance in a BCUCC. However, in the absence of a specific IFRS, the IASB (2018), IAS 8 para.10 criteria for developing an accounting policy mentions, among other, that the accounting solution should reflect the economic substance of the transactions, other events and conditions. The concept of 'commercial substance' as a technical cash flow test is in other contexts, for exchanges of non-monetary assets (IASB 2020, IAS 16, para. 25, IASB (2018), IAS 38, para. 46, as well as FASB (2020), FASB 845-10-30-4) and as part of the identification of a contract with a customer (IASB 2018, IFRS 15, paras. 9(d), BC40, BC41, as well as FASB (2020), FASB (2020), FASB ASC 606-10-25-1). IASB (2018), CF 2018, paras. 4.60, 4.61 introduce the general notion of substance of contractual rights and obligations, without which contractual terms are disregarded. Substance over form is also an integral aspect of faithful representation (IASB 2018, CF 2018, para. 2.12). Nevertheless, although undefined, there is a meaning of 'economic substance' that can be inferred from the example in IASB (2020), IFRS 3, paras. B18, BC100. This illustrates a newco that has no economic substance because it is formed to issue equity instruments to effect a business combination related to legal, tax or other business considerations that do not affect the identification of the acquirer. According to FASB (1985), FTB 85-5, superseded, an exchange of stock between two subsidiaries lacked substance when the minority interest did not change, there was no change in ownership and the only assets of the combined entity after the exchange equalled those of the partially owned subsidiary prior to the exchange. Accounting firms have developed guidance on substance as a pre-requisite for applying the acquisition method in a BCUCC and/or recognising a gain in a transaction under common control. For example, while a newco that is not a business would qualify the transaction as a reorganization and not a business combination, a newco that is created for the purpose of a change of control of a business, not only to issue equity instruments, would have economic substance (PWC 2020, paras. FAQ 29.39.1, FAQ 29.40.2). A different meaning of 'commercial substance' is that a BCUCC must not be used to circumvent limitations in GAAP to restate assets to fair value or the prohibition on the recognition of internally generated goodwill (EY 2020, para. 10.3.1). According to this interpretation, substance involves consideration of the purpose of the transaction, the involvement of third parties, 
whether it is conducted at fair value, the existing activities of the entities involved, and whether it is bringing entities together into a reporting entity that did not exist before. Although these sort of tests of substance generally consider the purpose of the transaction and the form of consideration, EFRAG (2011), paras. 4.7, 4.9, 4.26 reckon that these factors do not alter the commercial substance of the transaction for the combining entities (as opposed to the ultimate parent company) but may influence the choice of the measurement bases. Substance is sometimes intended as a substantive change in the ownership interest in the item transferred (EFRAG 2011, Appendix 3; IASB 2019, 23A June 2019, para. 12). Indicators for economic substance have been suggested, such as settlement in cash, involvement of publicly held entities, non-controlling interest in the receiving entity, and generation of synergies for the combining entities (IASB 2016, 23A April 2016, para. 24). The IASB Staff concluded that all BCUCCs have commercial substance for the receiving entity and the primary users of its financial statements, although this might not be the case for the controlling interests (IASB 2019, 23A April 2019 , para. 20). On a related issue, after discussing a common control model to the reporting entity (IASB 2008, DP 2008), IASB (2018), CF 2018 leaves the determination of the boundary of the reporting entity, including whether combined financial statements should be required for entities under common control, to the analysis of information needed by the primary users (IASB 2018, CF 2018, paras. 3.12-3.14, BC3.18, BC3.20, IFRS Interpretations Committee 2010, IFRIC Update January 2010).

\subsubsection{Ultimate Parent vs. Sub-Holdings in Identifying Controlling Party and Acquirer}

This paragraph intends to show that the definition of common control, transitory control, circumstances about a newco, and the identification of the acquirer pose unintended flexibility for a complex group as to whether and at what stage of several inter-company transfers to recognise gains or losses by not applying book value to a transaction. Although the IASB Project applies to both ultimate and intermediate parents, it does not provide a satisfactory conceptual answer, but it would bypass this issue by placing it into the scope of BCUCC transactions where a combining party had been previously externally acquired or would be subsequently externally sold, or the transaction is conditional to an initial public offering.

IASB (2020), IFRS 3, para. B1 qualifies a business combination as under common control by testing whether the ultimate party that controls all the combining entities does not change after the transaction. The transaction in Figure 1 is a BCUCC from the perspective of the ultimate parent $\mathrm{P}$ because there is no change in control, but a question arises at the level of the sub-holding P2, as it did not control subsidiary S before the transaction. If 'ultimate' is an absolute reference, P2 might have to develop an accounting policy. If 'ultimate' should be limited to the consolidated financial statements of the ultimate parent at reporting entity level, $\mathrm{P} 2$ would not be exempted from IASB (2020), IFRS 3 and would have to apply it. It is to be noted that IASB (2018), CF 2018, para. 3.8 states that financial statements should provide information from the perspective of the reporting entity.

Under IASB (2020), IFRS 3, para. B1 if control is transitory (i.e., for a brief period immediately before the transaction), a business combination does not qualify as being under common control. If in Figure $1 \mathrm{P} 2$ had been incorporated recently before the BCUCC and $\mathrm{P} 2$ were an entity operating a business, the control from $\mathrm{P}$ would not be transitory. In fact, IFRS Interpretations Committee 2006, IFRIC Update March 2006 states that the analysis of whether entities or businesses are under common control focuses on the combining entities that existed before the combination, in this case S and P2. Conversely, a newco that is created only for issuing equity shares to effect the transaction would not be identified as the acquirer (IASB 2020, IFRS 3, para. B18), i.e., there would be no business combination at the level of P2. Whether a newco created to effect an IPO soon after would constitute transitory control is still object of debate (IASB 2016, 23A April 2016; IASB 2017, 23A December 2017).

The angle from which the transaction is seen also affects the identification of the acquirer. One argument commonly used for advocating book value is that the transaction in Figure 1 may be seen either as a distribution of S to $\mathrm{P}$, which has then invested in $\mathrm{P} 2$, or a direct transfer to $\mathrm{P} 2$, which benefits $\mathrm{P}$. Therefore, an issue arises about what company is the accounting acquirer, whether $\mathrm{P} 2$ or $\mathrm{P}$. Some of the following considerations would back up one or the other of these conclusions. To identify the acquirer, IASB (2020), IFRS 3, para. 7 first directs to IASB (2018), IFRS 10 guidance on the entity that obtains control of another entity. In line with IFRS Interpretations Committee 2014, IFRIC Update May 2014, an entity that is identified as the acquirer is a parent for the purpose of IASB (2018), IFRS 10. Based on IASB (2018), IFRS 10, paras. 5-6, a parent is an investor that controls an investee, which is when it is exposed, or has rights, to variable returns from its involvement with the investee and has the ability to affect those returns through its power over the investee. Therefore, although P2 directly controls and $\mathrm{P}$ indirectly controls $\mathrm{S}$, it has to be seen which one under the specific circumstances better meet such a definition at the acquisition date. Then, if this determination is not conclusive, IASB (2020), IFRS 3 , para. 7 directs towards additional indicators. Among others, the acquirer is usually the entity whose owners have 
the ability to elect or appoint or to remove a majority of the members of the governing body of the combined entity, whose management dominates the management of the combined entity, or the entity that pays a premium over the pre-combination fair value of the equity interests of the other combining entity. (IASB 2020, IFRS 3, paras. B14-B15). At this level, the identification of the acquirer might depend on how the arrangement is structured. Furthermore, IASB (2020), IFRS 3, para. B18 specifies that a new entity is not the acquirer if formed to issue equity instruments to effect a business combination, while it may be the acquirer if it transfers cash or other assets or incurs liabilities as consideration. Finally, if the transaction were seen as a distribution of $\mathrm{S}$ to $\mathrm{P}$, at the same time P could not be considered the acquirer in a business combination under IASB (2020), IFRS 3, as it already had control of S, although indirect control through P1. Therefore, the structuring of the transaction and the identification of the acquirer would also affect whether IASB (2020), IFRS 3 may be an option.

\subsubsection{In-Substance Contributions and Distributions}

The purpose of the paragraph is to show that fair value consideration in a BCUCC offers judgmental latitude on inflated goodwill or artificial gain vs. equity accounting in the context of a fair value method, and different forms of substantive or non-substantive equity accounting in a book value context. Again, the IASB Project has declined to prescribe any form of presentation in equity (IASB 2016, 23B April 2016, para. 5), limiting to require disclosure (IASB 2020, 23A February 2020, para. 4).

In the context of a fair value method, the IASB Staff has noted that in a BCUCC the consideration transferred may be affected by factors different from the fair value of the acquired business and by synergies (IASB 2019, 23A December 2019, para. 8). According to some accounting firm guidance, if the consideration is different from the fair value of the business transferred there would be in substance a capital contribution or distribution. Recording this would be an accounting option. The theory is that a transfer other than at fair value is due to influence from a controlling party (PWC 2020, para. FAQ A1.40.1.1). It is to be noted that IFRS does not address this issue. IASB (2018), IFRS 2, para. 5 scopes out both business combinations and BCUCCs from share-based payment transactions. The only standard that refers to an undervalue transfer is IASB (2014), IAS 20 , para. 10A for a below-market rate government loan, where the benefit is treated as other income, not a contribution. The topic has been long discussed in the BCUCC project from the acquirer's perspective (IASB 2007, Paper 5C, para. 31). The concern is to avoid an acquirer's recognition of any inflated goodwill or any artificial gain while recognising any equity transactions. The so-called full fair value approach would recognise goodwill as the difference between fair value of the acquired business and fair value of the acquired identifiable net assets, while any difference between the fair value of the consideration transferred and the acquired business would be an equity contribution or distribution. Under the so-called ceiling approach, goodwill would be capped at the fair value of the acquired business. Excess consideration over the fair value of the acquired business would be an equity distribution. Under both methods there would be no gain. These methods would be consistent with IASB (2020), IAS 1 to recognise transactions with owners in their capacity as owners in equity, and with IASB (2020), IFRS 3 to account under that standard only for amounts that are part of the exchange for the acquiree (IASB 2018, 23A April 2018). A revised ceiling approach would provisionally determine goodwill as per IASB (2020), IFRS 3 and record a deemed distribution for any impairment under IASB (2018), IAS 36. The IASB Staff has rejected the full fair value approach and has suggested recognising what is a bargain purchase gain under IASB (2020), IFRS 3 as an equity contribution (IASB 2019, 23A December 2019, paras. 32, 41).

In the context of a book value method, under IASC (1999), IAS 22, superseded, any difference between share capital issued plus any additional consideration in the form of cash or other assets and the amount recorded for the share capital acquired was adjusted against equity. Under U.S. GAAP carryover method, adjustment is to capital accounts and any remaining amount to retained earnings or additional paid-in capital. Overton (2006) stated that consideration above parent's historical cost basis should be accounted for as a dividend to the parent, while the reverse situation as a contribution to capital by the parent.

\subsubsection{Fair Value versus Book Value}

The purpose of this paragraph is to show that groups may reach gain or loss opportunities by justifying the use of fair vs. book value, and by cherry-picking a particular definition of book value. On these aspects, the IASB Project is still at a discussion level.

Accounting firms have developed sets of not exhaustive indicators about the choice of which accounting method would better reflect the substance of a BCUCC. For example, as factors for acquisition accounting, PWC (2020), paras. A1.17, FAQ A1.45.1 indicate the existence of non-controlling interest; full payment in cash based on fair value (differently, EFRAG 2011, para. 4.25 sees the nature of the consideration irrelevant for the choice of a method because not affecting the economic substance); the fact that management of the combining entities is 
different before and after the transaction; purpose of the transaction that is preparatory for an IPO or other change in control or ownership as opposed to internal simplification; tax planning; or a capital reorganization. Simply moving an entity from one to another part of the group would call for book value, whereas the fact that the acquirer is a separate legal entity in its own right might be an argument for acquisition accounting (KPMG 2020, para. 5.13.50.30). Practice is diverse about what company book values refer to, including the transferring controlling entity (e.g., its carrying amount of the investment in the transferee in the case of a transfer of the investment in a subsidiary), the transferred entity, i.e., the transferee (both in the case of a transfer of the entire company or of a group of assets and liabilities of that company), the carrying amounts in the consolidated financial statements of the ultimate parent, or of any intermediate parent. As said, U.S. GAAP gives priority to the historical cost in the parent of the entities under common control. FASB (1990), EITF Issue 90-5, superseded, required that in its consolidated financial statements an acquiring subsidiary used the carrying amounts of the acquired subsidiary in the consolidated statements of the parent. Accounting firms have developed their own guidance, ranging from contemplating all options (for example KPMG 2020, para. 5.13.60.1), to considering consistency with previous similar transactions but justifying the use of the controlling party's consolidated amounts because the acquiree has effectively taken on the group's ownership of the acquiree (EY 2020, para. 10.3.3.2), to listing a series of indicators to overwrite a general presumption to use the amounts in the consolidated statements of the highest entity that has common control (PWC 2020, paras. A1.19, A1.21, FAQ A1.21.1, FAQ A1.44.1). Based on this, a leaning towards the highest consolidated statements would come when the transaction is in preparation for a listing or sale, the business transferred was established or acquired recently and therefore those consolidated statements are more updated. The consolidated statements of an intermediate parent would sound more appropriate for a reorganization occurred entirely within a sub-group, or when there are third party shareholders in the subgroup. Finally, the books of acquired entity itself would be more relevant if the users of the financial statements of the receiving entity previously relied on those of the transferee, or the timing of its establishment of acquisition from outside the group was far in the past. The transferee would also be used where the transaction is not a business combination but a reorganization (e.g., when a newco that is not a business is inserted as an intermediate parent of an existing entity that is a business). IASB (2016), Agenda ref. 5 April 2016, paras. 16-17 have suggested the use of the transferred party's amounts and a prospective approach, as this looks at the transaction from the eyes of the combining enterprises, as opposed to parent's amounts and a retrospective approach, which provide the perspective of the controlling party, although pro-forma disclosures could be considered. The choice of what company book values should refer to can significantly affect the financials of the receiving company. In fact, if the transferred business had been acquired from outside the group, using predecessor's consolidated financial statements amounts (whether at ultimate or intermediate parents, and those amounts may differ from each other) means recording assets and liabilities at IASB (2020), IFRS 3 amounts, including fair value adjustments and possibly goodwill, as recorded by that parent at original acquisition date and adjusted based on consolidation techniques up to the date of the BCUCC. Therefore, even if the predecessor's carryover basis is technically a book value method, in that situation it would approximate an acquisition method, and it may look as a safer method than IFRS 3 to achieve a similar result. However, this would not reflect a new valuation of the business combination at the BCUCC acquisition date (as when IASB 2020 , IFRS 3 is applied) but of the original acquired business carried forward to the new transaction date. Note that on initial recognition of a business combination, if the investment in a subsidiary or a disposal group that is a business qualifies as a held for sale, based on the acquirer's perspective, the acquirer measures it at its fair value less costs to sell (similarly under FASB 2020, Subtopic 360-10). If the transaction does not qualify as a business combination, the acquirer measures the held for sale disposal group at the lower of its carrying amount had it not been so classified and fair value less costs to sell (IASB 2018, IFRS 5, paras. 5.16, BC45, IASB 2020, IFRS 3, para. 31).

\subsection{Perspective of the Individual Financial Statements of the Receiving Entity}

This section discusses individual, not separate financial statements. As explained by IASB (2014), IAS 27, paras. 6-7, BC10.D-BC10E, they are not the same. This matters, because if a transfer refers to a group of assets and liabilities that is a business (i.e., an unincorporated business), as opposed to as transfer of an investment in the transferred entity, the receiving entity that is the acquirer under IASB (2020), IFRS 3 would ordinarily report that group of assets and liabilities as part of its own assets and liabilities and apply IASB (2020), IFRS 3 to its individual financial statements. Conversely, separate financial statements account for an investee as an equity investment (IASB 2014, IAS 27, para. 7). If the business combination is under common control, the same IASB (2020), IFRS 3 exclusion that applies in consolidated financial statements also applies in individual financial statements. In the case the acquisition of a group of assets and liabilities does not constitute a business, as defined in IASB (2020), IFRS 3, the transaction is not a business combination and therefore is outside the scope 
of the standard. The acquirer allocates the cost of acquisition to the individual identifiable assets and liabilities on a relative fair value basis at the date of purchase, with no goodwill or bargain gain (IASB 2020, IFRS 3, para. $3.2 b)$. In addition, there is no deferred tax asset or liability for the initial recognition of an asset or liability in a transaction that is not a business combination and at the time of the transaction affects neither accounting profit nor taxable profit or tax loss (IASB 2018, IAS 12, paras. 15b and 24).

\subsection{Perspective of Separate Statements of the Receiving Entity and Higher-level Parent}

The purpose of the section is to show the great latitude in gain or losses outcomes that diverse accounting practice (even some that are not rooted on IFRS grounds) may achieve for separate financial statements.

\subsubsection{Ramifications of Using the Cost Method}

If, in its separate financial statements, the acquirer uses cost method under IASB (2014), IAS 27, para. 10, it first needs to check whether IASB (2014), IAS 27, paras. 13-14 guidance for certain group reconstructions applies, which cannot be applied by analogy. IASB (2014), IAS 27, para. BC27 states that for other types of reorganizations or non-exempt common control transactions entities will follow their accounting policies for such transactions, although it is not said what these policies may be. In another context, IFRS Interpretations Committee 2012, IFRIC Update May 2012 clarified that cost of an investment at initial recognition date is the purchase price and directly attributable expenditures that are necessary to obtain it, such as professional fees for legal services, transfer taxes and other transaction costs. This does not leave great space to interpret what cost is, unlike diversity in practice as reported below. Note that in IFRS there is no base to write up P's investment in P2 under the cost method when the consideration paid by P2 to P1 is higher than P1's carrying amount of the investment in S (in conjunction with an impairment of P's investment in P1. According to some, P would record this side-away transfer in Figure 1 as a change in the investment accounting in P1 and a corresponding opposite change in the investment account in P2, and this would not contravene cost method under IASB (2014), IAS 27 (PWC 2020, para. FAQ A1.36.1.1).

\subsubsection{Ramifications of Using the Equity Method}

IFRS Interpretations Committee 2013, IFRIC Update May 2013 argues whether the IASB (2020), IFRS 3 scope exclusion applies to the equity method in separate financial statements. It noted some diversity in practice because, on one hand, IASB (2018), IAS 28, para. 32 does not have such a scope exemption but, on the other hand, IASB (2018), IAS 28, para. 26 states that several equity method procedures are like consolidation procedures and that the concepts underlying the procedures used in accounting for an acquisition of a subsidiary are also adopted for the acquisition of an interest in a subsidiary. IFRS Interpretations Committee 2017, IFRIC June 2017, September 2017 and IFRS Interpretations Committee 2018, IFRIC Update January 2018 stated that an IFRS standard applies to a transaction that falls within its scope even if it is under common control unless that standard specifically excludes it, hence it gave more prominence to IASB (2018), IAS 28, para. 32, therefore equity method should apply as normal. Conversely, according to EY (2020), para. 10.5, there would be an accounting option choice between applying IASB (2018), IAS 28 and the IASB (2020), IFRS 3 scope exclusion by analogy. In the former case, there would be another accounting policy choice to threat any difference as equity distribution or contribution instead of goodwill or bargain purchase gain. In the former case where book value is used, the company would recognise the investment at its predecessor equity-accounted carrying amount on the date of acquisition, with any difference between that amount and the consideration given being an equity contribution or distribution.

If the ultimate parent P uses the equity method and under IASB (2018), IAS 28, para. 41A determines that P1 disposing of S in exchange for a compensation lower than the P1's carrying amount of the investment in S means that P's investment in P1 is impaired, P would test its investment for impairment under IASB (2018), IAS 36 (IASB 2018, IAS 28, paras. 42, BCZ46). Also, P will have to pick up equity income in P1 under IASB (2018), IAS 28, para. 10. If P1 records a loss or a gain on disposal of $\mathrm{S}, \mathrm{P}$ will record its pro-rata share (in Figure 1, $100 \%$ ) of it. Similarly, P will record an equity pick up related to its share (in Figure 1, 100\%) of P2's bargain gain in acquiring S. Note that an issue would arise if the transfer of S from P1 to P2 were not in exchange for cash but against the issuance of new shares of P2. IASB (2013), Proposed ED 2013, para. 10(d) concluded that an investor's share of an investee's net assets changes other than profit or loss or other comprehensive income and distribution received is recognised in the investor's equity. This case would include the investee issuing additional shares. All the discussion so far related to $\mathrm{P}$ assumes the view that $\mathrm{P} 1$ and $\mathrm{P} 2$ transact as separate legal entities. It is important to note that this comes from applying IASB (2018), IAS 28 extant guidance. An alleged book value method would instead assume that this is in essence a distribution from P1 to P and a contribution from $\mathrm{P}$ to $\mathrm{P} 2$, but this is not backed up by any IFRS extant pronouncements. 


\subsubsection{Ramifications of Using Fair Value under IASB (2019), IFRS 9}

While an investment in a subsidiary would normally be scoped out of IASB (2019), IFRS 9 by IASB (2019), IFRS 9, para. 2.1, it may be brought back to it by IASB (2014), IAS 27, para. 10 by a company election in its separate financial statements. In this case, the acquirer would initially recognise the investment in an unlisted subsidiary at the transaction price and subsequently all changes in fair value in profit or loss. The fair value of a financial instruments at initial recognition is normally the transaction price, i.e., the fair value of the consideration given or received (IASB 2019, IFRS 9, para. B5.1.1). However, if its fair value differs from the transaction price, the entity uses the latter, unless the fair value is evidenced by a quoted price in an active market for an identical asset or based on a valuation technique that uses only data from observable markets so-called day-one gain or loss (IASB 2019, IFRS 9, para. 5.1.1A). Therefore, this case does not apply to a subsidiary that is not listed. If the entity cannot use fair value based on the point above, after initial recognition it recognises the deferred difference between the fair value at initial recognition and the transaction price as a gain or loss only to the extent that it arises from a change in factor (including time) that market participants would take into account when pricing the asset (so-called day-two gain or loss). IASB (2019), IFRS 9, para. B5.2.2A goes on with saying that subsequent recognition of those gains and losses must be consistent with the requirements of IASB (2019), IFRS 9. In other terms, if the investment in the subsidiary is carried at fair value by election, it would be classified as at fair value through profit or loss, which would lead to book any subsequent change in fair value in profit or loss. If $\mathrm{P}$ uses fair value in its separate financial statements, it will record a fair value gain or loss on $\mathrm{P} 1$ for any difference between the consideration received and the fair value of $\mathrm{S}$, and on $\mathrm{P} 2$ for any difference between the consideration paid and the fair value of $\mathrm{S}$.

\subsubsection{Combinations of Methods}

If P uses the cost method, its entries are the same irrespective of the method used by P2. If both P2 and P use the equity method, P's equity-method income pick up on P2 reflects any P2's subsequent equity-method income pick up on S. If P2 uses fair value under IASB (2019), IFRS 9 and P uses the equity method, P's equity-method income pick up on P2 reflects any P2's subsequent fair value gain or loss on S. If both P2 and P use fair value under IASB (2019), IFRS 9, P's subsequent fair value gain or loss on P2 reflect recorded changes in the fair value of P2's investment in S. If P uses fair value under IASB (2019), IFRS 9 and P2 uses the cost method, P's fair value gain or loss on P2 reflects unrecorded changes in fair value of P2's investment in S.

\subsubsection{The Debate on Book Value, Exchange Amount and Fair Value Methods}

Practice is diverse as well as accounting firm guidance (IASB 2007, Paper 5C, para. 20). Some have said that, although IFRS does not specify the accounting for common control transactions in separate financial statements, the acquirer has an accounting policy to either apply the IASB (2020), IFRS 3 exclusion by analogy and use book value, or use fair value, or exchange amount accounting. These are considered as alternative ways of quantifying cost. The basis for fair value would be justified on the acquirer and acquiree being separate entities in their own rights. Conversely, the rationale for book value (represented by the carrying amount of the investee in the separate financial statements of the transferor) would be that there is a distribution to or contribution from shareholders which does not result in profit or loss as a capital transaction with equity participants. Exchange amount accounting would not be appropriate when there is no consideration or there is a nominal consideration, which would call for using an accounting policy choice in respect of demergers (KPMG 2020, paras. 5.13.20.10, 12, 5.13.110.20-30, 35). Seen from extant IFRS, such a position shows several conceptual inconsistencies. First, while IASB (2020), IFRS 3 has a scope exclusion for BCUCCs, in an entity's separate financial statements the acquisition of an equity investment in a subsidiary is not a business combination, and the appropriate standard is IASB (2014), IAS 27. Therefore, the IASB (2020), IFRS 3 scope exclusion has no ground in separate financial statements where an investment in a subsidiary is measured at cost method. Also, by applying IFRS Interpretations Committee 2018, IFRIC Update January 2018, as IASB (2014), IAS 27 does not exclude common control transactions, the IASB (2020), IFRS 3 scope exclusion would not be applicable. Second, a company that applies fair value in its separate financial statements, applies IASB (2019), IFRS 9, not IFRS 2020, IFRS 3. Therefore, the IASB (2020), IFRS 3 scope exclusion has no ground in separate financial statements where an investment in a subsidiary is measured at fair value under IASB (2019), IFRS 9. Third, at least for non-listed companies, at acquisition date there is no difference between an exchange amount method and fair value under IASB (2019), IFRS 9, as discussed above. Fourth, IFRS Interpretations Committee 2012, IFRIC Update May 2012 gave no latitude in interpreting what cost is. In conclusion, exchange amount and book value are not alternative a way of quantifying cost. The alleged fair value method is different from the use of fair value under IASB (2019), IFRS 9 in the separate financial statements of the transferor (in Figure 1, P1), which means that the carrying amount of the subsidiary $\mathrm{S}$ is already at fair value. Under this alleged alternative method, the 
investment account was not carried at fair value, and is fresh measured at fair value. As this method considers the transaction as a distribution to owners (in Figure 1, P), from the perspective of the transferor this determines a gain or loss under IASB (2018), IFRIC 17, para. 14 (used here by analogy) for the difference between the carrying amount of the assets distributed (e.g., at cost) and the carrying amount of the dividend payable (which is recognised at fair value).

\subsubsection{Non-reciprocal Distributions for the Acquirer}

This topic comes in connection with the discussion about demergers later in this article, from the perspective of the receiving entity obtaining a non-cash distribution. IASB (2018), IFRIC 17 does not apply to the company that receives a distribution (IASB 2018, IFRIC 17, para. 8). Some accounting firm guidance refers to this as a transfer of a subsidiary by dividend, where a determination would be required as to whether the distribution is a return on capital, i.e., dividend income, or a return of capital, i.e., a reduction or reallocation of the cost of investment (PWC 2020, para. A1.37). Contrary to this view, IASB (2014), IAS 27, para. 12 mandates recognition in profit or loss of dividends from a subsidiary, a joint venture or associate in the parent's separate financial statements at cost method, unless the entity elects the equity method where the dividend is a reduction from the carrying amount of the investment account. In May 2008, the requirement to separate the retained earnings of an entity pre-acquisition and post-acquisition components as a method for assessing whether a dividend is a recovery of the investment was removed from IFRS (IASB 2014, IAS 27, para. BC18), with the additional introduction of a special impairment test (IASB 2018, IAS 36, para. 12h). The only exception is when a company elects fair value under IASB (2019), IFRS 9 for its investment in a subsidiary, associate or joint venture and uses the IASB (2019), IFRS 9 election to present in other comprehensive income changes in the fair value of equity instruments that are not held for trading. Only in this case IASB (2019), IFRS 9, paras. 5.7.1A, 5.7.6, B5.7.1, BC5.25a state that those dividends are recognised in profit or loss unless the dividend clearly represents a recovery of part of the cost of the investment.

\subsection{Perspective of the Transferor}

\subsubsection{Review under IASB (2018), IFRS 5}

This paragraph intends to show that, by agreeing the consideration and timing of a sale, a transferor may avoid an impairment loss, and by scoping the object of transfer may define the profit or loss geography of such a loss.

IASB (2018), IAS 36. para. 12 considers plans to dispose of an asset before the previously expected date as an indicator that the asset may be impaired. However, once an asset meets the criteria to be classified as held for sale (or it is included in a disposal group that is classified as held for sale), it is excluded from the scope of IASB (2017), IAS 36 and is accounted for in accordance with IASB (2018), IFRS 5 (IASB 2018, IAS 36, para. 2, IASB 2018, IFRS 10, para. BCZ187). If the respective criteria are met, a commitment to a sale plan involving loss of control of a subsidiary would qualify an investment in a subsidiary to be transferred as held for sale (IASB 2018, IFRS 5, para. 8A), which would require accounting for under IASB (2018), IFRS 5 if that investment were measured at cost or at the equity method (IASB 2014, IAS 27, para. 10). If an investment in a subsidiary is classified as held for sale, it would also likely qualify as a discontinued operation. In fact, a subsidiary is a component for its parent (IASB 2018, IFRS 5, para. 31). If the subsidiary represents a separate major line of business, it is part of a single coordinated plan to dispose and is classified as held for sale, it will meet the definition of a discontinued operation (IASB 2018, IFRS 5, para. 32), triggering separate presentation in profit or loss from discontinued operations (IASB 2018, IFRS 5, para. 33). For a transfer of a group of assets and liabilities that does not meet the definition of a discontinued operation, held for sale remeasurement gain or loss is presented in profit or loss from continuing operations (IASB 2018, IFRS 5, para. 37 Such requirements apply irrespective of whether the transaction is considered a sale of a demerger, with a disposal group held for distribution to owners (IASB 2018, IFRS 5, paras. 5A, 12A). In the case that in Figure 1 P1 first carves out a disposal group of S exclusively with a view to its subsequent disposal, at its acquisition date it would classify it as held for sale if the one-year requirement is met and it is highly probable that the other criteria that are not met at that date will be fulfilled within a short period following the acquisition, usually within three months (IASB 2018, IFRS 5, para. 11). This has implications for the acquirer, as noted above. U.S. GAAP has similar held for sale guidance (FASB 2020, FASB ASC 360-10-45).

\subsubsection{Disposal of or Loss of Control of a Subsidiary}

This paragraph shows what is probably the stronger motivation for a BCUCC, i.e., a gain on disposal by the transferor by negotiating the consideration. This Paragraph should be read in conjunction with the paragraph on the effect of the various methods of accounting for an investment in separate financial statements, and whether a transaction qualifies as a business combination, a BCUCC, or as a reorganisation, because in the latter two cases 
a gain might not be justified.

In the consolidated financial statements of an entity that loses control of a subsidiary, IASB (2018), IFRS 10, paras. 25 and B98 have no exception for BCUCCs to recognising gain or loss based on the fair value of the consideration received, so does FASB (2020), FASB ASC 810-10-45-5. Although IASB (2018), IFRS 10 does not define the consideration received, IASB (2020), IFRS 3, para. 37 defines the consideration transferred in a business combination. The acquirer measures the consideration transferred at fair value, as the sum of the acquisition-date fair values of the assets transferred by the acquirer, the liabilities incurred by the acquirer to the former owners of the acquire and the equity interests issued by the acquirer. Therefore, the fair value of the consideration received is not the fair value of the interest in the subsidiary but the fair value of the consideration that the former owners of the subsidiary receive in exchange. If that amount is higher than the carrying amount of the subsidiary, the transferor would record a gain on disposal, while the acquirer would potentially record fair value adjustments and goodwill. If part of the consideration is made of assets or liabilities of the acquirer that after the business combination remain within the combined entity under the control of the acquirer (for example, because transferred to the acquire rather than to its former owners), the acquirer measures them at their carrying amounts immediately before the acquisition date and does not recognise a gain or loss. If instead they are transferred to the owners of the subsidiary (P1 in Figure 1), P2 premeasures them at fair value at the acquisition date and recognises a resulting gain or loss on disposal (IASB 2020, IFRS 3, para. 38). IASB (2014), IAS 27 does not provide guidance for disposal of or loss of control of a subsidiary in separate financial statements. It may be argued that IASB (2018), IFRS 10 could be applied by analogy, also in the light of IFRS Interpretations Committee 2018, IFRIC Update January 2018, as already mentioned. The seller would recognise a gain or loss on disposal, depending on whether the fair value of the consideration received is over or below the carrying amount of its investment in the subsidiary. As mentioned, different methods permitted in separate financial statements under IFRS as well as other alleged methods used in practice may affect the transferor gain or loss outcomes vs. equity accounting.

\subsubsection{Whether Fair Value of the Business Transferred May Differ from Fair Value of the Business Received}

The issue in this paragraph is whether the transferor may record a gain on disposal (fair value of the consideration received higher than carrying amount of the investment) and the acquirer record a bargain purchase gain (fair value of the consideration transferred lower than the IASB 2020, IFRS 3 value of the acquisition-date net assets acquired). The discussion in this paragraph should be read in conjunction with the debate on in-substance contributions and distributions addressed above.

On one hand, following the reasoning in IASB (2020), IFRS 3, paras. BC163, BC313, the IASB notes that synergies from combining two or more businesses are part of the price paid for goodwill, so a negative goodwill (i.e., a bargain purchase gain) would not be expected. On the other hand, along the line of IASB (2020), IFRS 3 , para. $\mathrm{BC} 286$, acquirer's synergies are not necessarily factored into the price paid in a business combination. IASB (2020), IFRS 13, paras. 89, BC174 state that when using Level 3 inputs to determine fair value and entity must adjust its estimates for something particular to the entity that is not available to other market participants (e.g., an entity-specific synergy). It would not be given that market participants value it in combination to the acquirer's business (IASB 2020, IFRS 3, para. B3c). However, this position would be difficult to justify in a transaction under common control, where the higher-level parent is aware of the facts of both businesses. In the case of a carve out of a business from the subsidiary and its subsequent disposal by its parent, it would be expected that the price of the first transfer would be the same as, or consistent with, the price of the second transfer within the same group, adjusted for any difference in scope and timing that may justify a difference in valuation. This article has explained the application of the concept of substance for the acquirer. It may be argued that to the extent a BCUCC is only devised by the acquirer to recognise internally generated goodwill or fair value write up of assets that would not be permitted under GAAP other than in a business combination, the concept of substance would also prohibit the corresponding recognition of a gain on disposal by the transferor.

\subsection{Interactions with Demergers or Spin-offs for the Transferor}

This section shows grey areas about the determination of whether a disposal is part of a business combination, a BCUCC, a distribution in kind, or a demerger, which may head for gain or no gain recognition for the transferor.

IASB (2018), IFRS 10, para. BZ184 defines a spin-off as the transfer of a company's shares in a subsidiary to its own shareholders with the result that the entity loses control of the subsidiary. Similarly, IASB (2018), IFRIC 17, para. $\mathrm{BC} 14$ uses the term spin-off, split-off or demerger when shares or the businesses of group entities are distributed to shareholders. IASB (2018), IFRIC 17 has additional definition requirements. It should be a non-reciprocal distribution of non-cash assets or a distribution that gives owners a choice of receiving either 
non-cash assets or a cash alternative by an entity to its owners acting in their capacity as owners. Non-cash assets include a business as defined in IASB (2020), IFRS 3, an ownership interest in another entity, or a disposal group under IASB (2018), IFRS 5. U.S. GAAP classifies spinoffs, split-ups, and split offs as part of non-reciprocal transfers with owners, as stockholder distributions of capital stock of subsidiaries that involve disposing of all or a significant segment of the entity. A non-reciprocal transfer is a transfer of non-monetary assets for which no assets are received or relinquished in exchange. It defines a split-off as a transaction in which a parent exchanges its stock in a subsidiary for parent stock held by its shareholders. A spin-off is the transfer of assets that constitute a business by a 'spinnor' into a new legal spun-off entity ('spinnee') followed by a distribution of the shares of that spinnee to its shareholders without the surrender by the shareholders of any stock of the spinnor. A reverse spin-off is when the legal form of the transaction is different from its substance so that the spinnee will be the continuing entity (FASB 2020, FASB ASC 845-10-05-4, 5, 845-10-20, 505-60-20).

\subsubsection{Scoping for the Transferor}

IASB (2018), IFRIC 17, para. 3, 5 scope out a transaction between entities or businesses under common control. IASB (2020), IAS 1, para. 7 defines owners as holders of instruments classified as equity. IASB (2018), IAS 32, para. BC4H refers to an owner as a holder of equity instruments. FASB (2020), FASB ASC 845-10-20 has a similar definition. Therefore, both the parents and the individual owners of the ultimate parents are owners. In Figure 1, a transfer from $\mathrm{P} 1$ of $\mathrm{S}$ to $\mathrm{P} 2$ or $\mathrm{P}$ is a business combination under common control, hence scoped out of IASB (2018), IFRIC 17. Conversely, a transfer of S to P's individual owners is not a business combination because there is only one business (S) that is not combined with other business, while it is a demerger. The second feature of a demerger definition under IASB (2018), IFRIC 17 is the distribution being not reciprocal. According to some accounting firms, a disposal at nominal consideration would be an in-substance demerger rather than a loss of control under IASB (2018), IFRS 10 (KPMG 2020, para. 5.13.100.60). Conversely, the absence of a consideration does not per se scope it out of IASB (2018), IFRS 10 in the consolidated financial statements of the transferor. In fact, IASB (2018), IFRS 10, para. B98 states that the transferor must recognise the consideration received, if any. So, the standard admits that there might be no consideration. In addition, IASB (2018), IFRS 10 applies to all transactions where a parent loses control of a subsidiary, without scope limitations. Unfortunately, IASB (2018), IFRS 10, para. BCZ184 scopes demergers out of that standard. The implications of the concept of consideration are not symmetrical. From the acquirer's perspective, IASB (2020), IFRS 3, para. 37 includes any equity interests issued by the acquirer into the notion of consideration transferred in a business combination. Equity interest issued may be new shares issued by P2 to P or P1 but also an increase in the nominal value of P2's shares. IASB (2020), IFRS 3, para. 43 includes cases of an acquisition without consideration. Finally, IASB (2020), IFRS 3, para. 33 states that in the formula to determine goodwill when there is no consideration the acquirer must use the acquisition-date fair value of the acquirer's interest in the acquiree in the place of the acquisition-date fair value of the consideration transferred. For the transferor instead, a disposal without consideration will be a non-reciprocal transaction, falling within the scope of IASB (2018), IFRIC 17 only when it is a demerger and not a transaction under common control.

In conclusion, a disposal of a business (whether housed or not in a subsidiary) to an entity under common control with loss of control will trigger a deconsolidation gain or loss in the transferor's consolidated financial statements based on the fair value of the consideration received. Conversely, a demerger is scoped out of IASB (2018), IFRS 10 and would be accounted for under IASB (2018), IFRIC 17. However, as there are mixed views as to when a transfer is part of a BCUCC or a demerger, some have concluded that the transferor has an accounting policy to account for a demerger either at book value of the non-cash assets distributed or at fair value at the date of the transaction (KPMG 2020, para. 5.13.100.20). As mentioned, IASB (2018), IFRS 5 requirements apply to a disposal group held for distribution to owners. The IASB Project does not provide an answer.

IASB (2018), IFRS 10 does not apply to the separate financial statements of the transferor. The same conclusions on IASB (2018), IFRIC 17 explained above apply here because IASB (2018), IFRIC 17 applies to individual, separate, and consolidated financial statements of the transferor. Conversely, a distribution of some of the ownership interest in S without P1 losing control of it would fall under IASB (2014), IAS 27 for its separate financial statements, not IASB (2018), IFRIC 17 (IASB 2018, IFRIC 17, para. 7). Again, some accounting firms have concluded that here the transferor has an accounting policy of using either book value of the non-cash assets distributed or fair value at the date of the transaction (PWC 2020, paras. A1.40, FAQ A1.40.1). Therefore, a gain or loss on disposal may arise, but this would call for the test of substance of the transaction from the transferor's perspective (see above) as a pre-requisite to recognise a gain or loss on disposal 
that would come from applying IASB (2018), IFRIC 17 by analogy (PWC 2020, para. FAQ A1.40.1.1). Again IASB (2018), IFRS 5 requirements first apply.

\subsubsection{U.S. GAAP Accounting for Spin-offs}

If the controlled group of assets received meets the definition of a business for the owners of the entity, fair value is used, and Topic 805 Business combinations applies (FASB 2020, FASB ASC 845-10-55-2). However, for spin-offs and other forms of reorganizations or liquidations of non-monetary assets that constitute a business, the ordinary deconsolidation guidance for the transferor under Subtopic 810-10 is waived and the recorded amount (e.g., the carrying amount of a wholly owned or consolidated subsidiary whose shares are distributed to the parent's shareholders), after any impairment, is used, hence with no gain or loss recognition. As an exception, a distribution to owners of a consolidated or equity-method subsidiary is at fair value if not made on a pro rata basis or if the targeted stock was created in contemplation of the subsequent split-off (FASB 2020, FASB ASC $810-10-40-5 ; 855-10-30-10,12,13 ; 505-60-25-2)$. Therefore, here U.S. GAAP uses a book value approach as opposed to fair value in IASB (2018), IFRIC 17. CESR 2009, 09-1134, Decision ref EECS/1209-14 ruled the use of pooling of interests under U.S. GAAP as acceptable to an IFRS issuer that had made a spin-off and distributed a share of it to its shareholders on a pro-rata basis, still maintaining the control of the spun-off entity. The enforcement decision was on the basis that the first phase of the spin off was a transaction under common control. As control of the spun-off entity had not been relinquished, it was a change in ownership interest in a subsidiary with no loss of control that should be accounted for as an equity transaction. For a non-reciprocal transfer where the non-monetary asset given up does not meet the definition of a business to stockholders, the first determination is whether FASB (2020), FASB ASC Topic 606 guidance for revenue should be applied if it refers to a contract with a customer. If this is not the case, the second step of analysis is whether this is a transfer of an ownership interest or a variable interest in a consolidated subsidiary that is not a business or non-profit activity to not customers and all the assets of the subsidiary are non-financial assets and/or in substance non-financial assets. In such a case FASB (2020), FASB ASC Subtopic 610-20 applies, in practice looking through to the derecognition treatment that is applicable to each distinct asset within the subsidiary based on its nature, such as PPE, intangible asset or arising from a contract with a customer, with gain or loss recognition. However, this Subtopic does not apply in transfers between entities or persons under common control (FASB 2020 , FASB ASC $610-20-15-3,4 ; 610-20-15-10)$. If neither of the two tests is passed, the transferor records the non-monetary asset distributed at fair value with a gain or loss on disposal if fair value is objectively measurable and would be clearly realizable to the distributing entity in an outright sale at or near the distribution date. Unlike IASB (2018), IFRIC 17, U.S. GAAP regulates the accounting of the receiving entity, which records the non-monetary asset received in a non-reciprocal transfer at fair value (FASB 2020, FASB ASC 845-10-30-1).

\subsection{Perspective of the Individual Financial Statements of the Transferred Entity}

In the case of a transfer of a group of assets and liabilities (as opposed to the transfer of the investment in the subsidiary by its parent), if the disposal group meets the definition of held for sale, a re-measurement at the lower of its carrying amount and fair value less costs to sell will be required under IASB (2018), IFRS 5 (as well as FASB 2020, FASB ASC 360-10) at the date of such a classification. A determination is needed as to whether what is transferred is a business. If it is not, gains or losses on disposal will depend on the standards applicable to the specific assets or liabilities that are transferred, to be recognised by the date of sale or otherwise at de-recognition (IASB 2018, IFRS 5, para. 24). If it is a business, IASB (2018), IFRS 10, para. BC190E concludes that full gain or loss should be recognised on the loss of control of a business, regardless of whether that business is housed in a subsidiary or not. Thus, such a guidance may be applied by analogy to individual (not separate) financial statements.

\section{Conclusions}

This article has answered the research question by showing how in the absence of guidance, groups may address grey areas to achieve gain or loss opportunities through 1) options of IFRS 3 vs. book value methods; 2) concluding for a business combination vs. BCUCC vs. re-organisation based on the concept of substance; 3) arguing at the level of sub-groups about the definition of common control, transitory control, circumstances about a newco, and the identification of the acquirer; 4) achieving inflated goodwill or artificial gain vs. equity accounting in the context of a fair value method, and different forms of substantive or non-substantive equity accounting in a book value context; 5) cherry-picking a particular definition of book value; 6) using different accounting methods in the separate financial statements of different members of the group; 7) avoiding an impairment loss by agreeing the consideration and timing of a sale, or defining the profit or loss geography of such a loss by scoping the object of transfer; 8) obtaining a gain on disposal by the transferor by negotiating the 
consideration depending on the accounting method used; 9) determining a fair value transferred that differs from the fair value received; 10) qualifying a disposal as part of a business combination vs. a BCUCC vs. distribution in kind vs, a demerger. These issues are unaddressed by the IASB Project because this looks only at consolidated statements of the receiving entity, while a multinational group focus is often on how to achieve a gain or loss in the separate financial statements of a member of the group (the transferor, the transferred entity, or the receiving entity) or increased enterprise value at a sub-holding level.

Cross-company consistency in policies and substance may reveal gain/loss arbitrage. Although each legal company follows its own accounting policies, in practice it is common to have guidelines from the parent company for consistency to group accounting policies. Therefore, a gain on disposal of a business recognised by a transferor based on the fair value of the consideration received would likely correspond to a higher value of assets acquired (and possibly goodwill) for an acquirer that accounts for the acquisition of that business under IASB (2020), IFRS 3. An acquirer's bargain purchase gain might correspond to a transferor's loss on disposal. An asset transfer of a business from one company to another which uses IASB (2020), IFRS 3 in its individual financial statements, and then a transfer of the investment in that subsidiary (including the now integrated business) to another member of the group would suggest that also the new acquirer uses IASB (2020), IFRS 3 in its consolidated financial statements, while a transfer at book value would also ordinarily correspond to an acquisition at book value.

The unresolved dialectics between IASB (2018), IFRS 10, IASB (2020), IFRS 3 and IASB (2018), IFRIC 17 plays a key role in gain recognition, because the use of fair value versus book value by the transferor interacts with the decision of the receiving entity about using a fair value versus a book value method, and accounting practice has been open to an option of fair value or book value for the transferor where the transaction falls outside of IASB (2018), IFRIC 17. The EFRAG DP 2011 (para. 3.12.b, Appendix 1.13, Appendix 3.1) is among the supporters of the analogy to the principles in IASB (2018), IFRIC 17. In particular, the theory is that the nature of a reciprocal versus non-reciprocal transaction would not alter its economics and there is a loss of control of a business irrespective of whether there is a disposal to another group member or a demerger.

A transferor desiring to achieve a gain on disposal of a business will have to take into consideration a possible loss from measuring the disposal group under IASB (2018), IFRS 5, irrespective of whether the transaction is a disposal or a distribution to owners. Measurement under IASB (2018), IFRS 5, although not at fair value but based on fair-value, would also set a precedent for the measurement of the subsequent disposal, as well as for the valuation by the transferee. Also, a bargain purchase gain would be difficult to justify once that reference is set.

Although a transferor's gain on disposal or an acquirer's bargain purchase gain under IASB (2020), IFRS 3 would be eliminated in the consolidation of the common control parent, from a real economy perspective, different associations of assets and liabilities under different intermediate parents may create gains or losses at each level, as well as synergies or change their economics, and therefore their enterprise value multiples, possible with an eye to a future partial flotation.

This article shows researchers research directions for studying BCUCCs, empirically and theoretically, under the perspective of the interlink of all the affected group members.

\section{References}

Aboody, D., Kasznik, R., \& Williams, M. (2000). Purchase versus pooling in stock-for-stock acquisitions: Why do firms care? Journal of Accounting and Economics 29(3), 261-86. https://doi.org/10.1016/S0165-4101(00)00023-9

Asís Martínez-Jerez, F. (2008). Governance and Merger Accounting: Evidence from Stock Price Reactions to Purchase versus Pooling. European Accounting Review 17(1), 5-35. https://doi.org/10.1080/09638180701706013

Baker, C. R., Biondi, Y., \& Zhang, Q. (2009). Should merger accounting be reconsidered? A discussion based on the Chinese approach to accounting for business combinations. Università degli Studi di Brescia, Paper 91. Retrieved from https://www.unibs.it/sites/default/files/ricerca/allegati/Paper91.pdf

Baker, C. R., Biondi, Y., \& Zhang, Q. (2010). Disharmony in international accounting standards setting: The Chinese approach to accounting for business combinations. Critical Perspectives on Accounting, 21(2), 107-117. https://doi.org/10.1016/j.cpa.2009.11.004

Biancone, P. P. (2013), Business Combinations Under Common Control (BCUCC): The Italian Experience. GSTF Journal on Business Review (GBR), 2(3), 51-60. https://doi.org/10.5176/2010-4804_2.3.219 
Bonacchi, M., Marra, A., \& Shalev, R. (2015). Fair Value Accounting and Firm Indebtedness - Evidence from Business Combinations Under Common Control. https://doi.org/10.2139/ssrn.2587270.

Cavero Rubio, J. A., Amorós, M. A., \& Collazo, M. A. (2020), Economic Effects of Goodwill Accounting Practices: Systematic Amortisation versus Impairment Test. Spanish Journal of Finance and Accounting. https://doi.org/10.1080/02102412.2020.1778376

Elnahass, M., \& Doukakis, L. (2019). Market Valuations of Bargain Purchase Gains: Are These True Gains under IFRS? Accounting and Business Research 49(7), 753-784. https://doi.org/10.1080/00014788.2019.1609345

European Financial Reporting Advisory Group. (2011). Discussion Paper. Accounting for business combinations under common control (EFRAG 2011). Retrieved from http://efrag.org

EY. (2020). Accounting for business combinations involving entities or businesses under common control. (EY). Retrieved from http://www.ey.com

Financial Accounting Standards Board. (1985). FASB Technical Bulletin No. 85-5, Issues Relating to Accounting for Business Combinations, Including Costs of Closing Duplicate Facilities of an Acquirer, Stock Transactions between Companies under Common Control, Downstream Mergers, Identical Common Shares for a Pooling of Interests, Pooling of Interests by Mutual and Cooperative Enterprises (FTB 85-5). Superseded. Retrieved from http://www.fasb.org

Financial Accounting Standards Board. (1990). EITF Issue No. 90-5, Exchanges of Ownership Interests between Entities under Common Control (EITF Issue 90-5), Superseded. Retrieved from http://www.fasb.org

Financial Accounting Standards Board. (2005). EITF Issue No. 02-5, Definition of "Common Control" in Relation to FASB Statement No. 14 (EITF 02-5), Superseded. Retrieved from http://www.fasb.org

Financial Accounting Standards Board. (2020). FASB Accounting Standards Codification (FASB ASC). Retrieved from http://www.fasb.org

Fiume, R., Onesti, T., Romano, M., \& Taliento, M. (2015). Dialogue with standard setters. Business Combinations under Common Control: Concerns, Criticisms and Strides. Financial Reporting, 1, 107-126. https://doi.org/10.3280/FR2015-001005

IFRS Interpretations Committee. (2018). International Financial Reporting Interpretation 17, Distributions of Non-cash Assets to Owners (IFRIC 17). Retrieved from http://www.ifrs.org

IFRS Interpretations Committee. (2020). IFRIC Updates. Retrieved from http://www.ifrs.org

International Accounting Standards Board. (2007). Agenda Paper 5C, Information for observers (Paper 5C). Retrieved from http://www.ifrs.org

International Accounting Standards Board. (2008). Discussion Paper, Preliminary views on an improved conceptual framework for financial reporting - The reporting entity (DP 2008). Retrieved from http://www.ifrs.org

International Accounting Standards Board. (2013). Proposed Amendments to IAS 28, Equity method: share of other net asset changes (Proposed ED 2013). Retrieved from http://www.ifrs.org

International Accounting Standards Board. (2014). International Accounting Standard 20, Accounting for Government Grants and Disclosure of Government Assistance - As amended (IAS 20). Retrieved from http://www.ifrs.org

International Accounting Standards Board. (2014). International Accounting Standard 27, Separate Financial Statements - As amended (IAS 27). Retrieved from http://www.ifrs.org

International Accounting Standards Board. (2016). Agenda ref. 5, Cover paper (Agenda ref. 5 April 2016). Retrieved from http://www.ifrs.org

International Accounting Standards Board. (2016). IASB Staff Paper 23B, Application of the predecessor method (23B April 2016). Retrieved from http://www.ifrs.org

International Accounting Standards Board. (2016). IFRS Staff Paper, Agenda Ref 23A, Method(s) of accounting for BCUCC (23A April 2016), Retrieved from http://www.ifrs.org

International Accounting Standards Board. (2016). International Financial Reporting Standard 13, Fair Value Measurement - As amended (IFRS 13). Retrieved from http://www.ifrs.org 
International Accounting Standards Board. (2017). IASB Staff Paper 23A, Review of related projects (23A December 2017). Retrieved from http://www.ifrs.org

International Accounting Standards Board. (2018). Agenda ref 23, Update of the approaches being developed by the staff (23A April 2018). Retrieved from http://www.ifrs.org

International Accounting Standards Board. (2018). IFRS Conceptual Framework. Conceptual Framework for Financial Reporting (CF 2018). Retrieved from http://www.ifrs.org

International Accounting Standards Board. (2018). International Accounting Standard 8, Accounting Policies, Changes in Accounting Estimates and Errors - As amended (IAS 8). Retrieved from http://www.ifrs.org

International Accounting Standards Board. (2018). International Accounting Standard 12, Income Taxes - As Amended (IAS 12). Retrieved from http://www.ifrs.org

International Accounting Standards Board. (2018). International Accounting Standard 28, Investments in Associates and Joint Ventures - As amended (IAS 28). Retrieved from http://www.ifrs.org

International Accounting Standards Board. (2018). International Accounting Standard 32, Financial Instruments: Presentation - As amended (IAS 32). Retrieved from http://www.ifrs.org

International Accounting Standards Board. (2018). International Accounting Standard 36, Impairment of Assets As Amended (IAS 36). Retrieved from http://www.ifrs.org

International Accounting Standards Board. (2018). International Accounting Standard 38, Intangible Assets - As amended (IAS 38). Retrieved from http://www.ifrs.org

International Accounting Standards Board. (2018). International Financial Reporting Standards 2, Share-based Payment -As Amended (IFRS 2). Retrieved from http://www.ifrs.org

International Accounting Standards Board. (2018). International Financial Reporting Standards 5, Non-current Assets Held for Sale and Discontinued Operations - As Amended (IFRS 5). Retrieved from http://www.ifrs.org

International Accounting Standards Board. (2018). International Financial Reporting Standards 10, Consolidated Financial Statements - As Amended (IFRS 10). Retrieved from http://www.ifrs.org

International Accounting Standards Board. (2018). International Financial Reporting Standards 15, Revenue from Contracts with Customers - As Amended (IFRS 15). Retrieved from http://www.ifrs.org

International Accounting Standards Board. (2019). Agenda Paper 5, Joint CMAC and GPF Meeting (Agenda Paper 5 June 2019). Retrieved from http://www.ifrs.org

International Accounting Standards Board. (2019). IASB Staff Paper 23A, BCUCCs - Applying a current value approach to BCUCC (23A December 2019). Retrieved from http://www.ifrs.org

International Accounting Standards Board. (2019). IFRS Staff Paper, Agenda Ref 23A, Update on the staff's approach (23A April 2019). Retrieved from http://www.ifrs.org

International Accounting Standards Board. (2019). IFRS Staff Paper, Agenda Ref 23A, Transactions that do not affect non-controlling shareholders (23A June 2019). Retrieved from http://www.ifrs.org

International Accounting Standards Board. (2019). International Financial Reporting Standard 9, Financial Instruments - As amended (IFRS 9). Retrieved from http://www.ifrs.org

International Accounting Standards Board. (2020). Agenda ref 23A, Disclosure (23A February 2020). Retrieved from http://www.ifrs.org

International Accounting Standards Board. (2020). Discussion Paper. Business Combinations under Common Control (DP/2020/2). Retrieved from http://www.ifrs.org

International Accounting Standards Board. (2020). International Accounting Standard 1, Presentation of Financial Statements - As amended (IAS 1). Retrieved from http://www.ifrs.org

International Accounting Standards Board. (2020). International Accounting Standard 16, Property, Plant, and Equipment - As Amended (IAS 16). Retrieved from http://www.ifrs.org

International Accounting Standards Board. (2020). International Financial Reporting Standard 3, Business Combinations - As amended (IFRS 3). Retrieved from http://www.ifrs.org

International Accounting Standards Committee. (1999). International Accounting Standard 22, Business Combinations - As amended, then Superseded (IAS 22). Retrieved from http://www.ifrs.org 
Janowicz, M. (2017). Business combinations under common control in International Financial Reporting Standards - Is authoritative accounting guidance needed? Zeszyty Teoretyczne Rachunkowości, 93(149), 97-111. https://doi.org/10.5604/01.3001.0010.3191

KPMG. (2020). Common control transactions and Newco formations. (KPMG). Retrieved from http://kpmg.com

Onesti, T., Romano, M., \& Taliento, M. (2015), Acquisition-type or merger-type accounting? Further insights on transactions involving businesses governed by the same party(-ies). Financial Reporting, 2, 117-137 https://doi.org/10.3280/FR2015-002005

Overton, L. A. (2006). SEC Staff Speech, Remarks before the 2006 AICPA National Conference on Current $\begin{array}{llll}\text { SEC } & \text { PCAOB } & \text { Developments. }\end{array}$ http://www.sec.gov/news/speech/2006/spch121206lao.htm

PWC (Price Waterhouse Coopers). (2020). IFRS Manual of Accounting, Appendix 1 - Business combinations under common control, transfer of investments within groups and capital re-organisations. (PWC). Retrieved from https://www.inform.pwc.com

Rayburn, F. R., \& Powers, O. S. (1991). History of pooling of interests: Accounting for business combination sin the United States. Accounting Historians Journal, 18(2), 155-192. Retrieved from https://egrove.olemiss.edu/aah_journal/vol18/iss2/7

SEC (United States Securities and Exchange Commission). (2020). Regulation S-X (S-X). Retrieved from https://www.sec.gov

The Committee of European Securities Regulators (2008). $3^{\text {rd }}$ Extract from EECS's database of enforcement decisions (08-283). Retrieved from http://www.cesr.eu

The Committee of European Securities Regulators (2008). 4th Extract from EECS's database of enforcement decisions (08-966). Retrieved from http://www.cesr.eu

The Committee of European Securities Regulators (2009). $7^{\text {th }}$ Extract from EECS's database of enforcement decisions (09-1134). Retrieved from http://www.cesr.eu

\section{Copyrights}

Copyright for this article is retained by the author(s), with first publication rights granted to the journal.

This is an open-access article distributed under the terms and conditions of the Creative Commons Attribution license (http://creativecommons.org/licenses/by/4.0/). 